\title{
Two Drafts Written After a Fight
}

I.

Do I love you: yes or no?

The question: Is love a figure of speech?

I do-sometimes. Everyone wonders about our love; still, there can be no doubt I have been true (almost always).

Happily remembering the start of our romance; it seemed so promising ...

And is love continual happiness or not?

Is not what matters?

I cannot tell you who I want to spend my life with.

Enough about our love.

II.

Do I love you? Yes or no-the question is, love, a figure of speech. I do.

(Sometimes everyone wonders.)

About our love, still, there can be no doubt.

I have been true, almost always happily remembering the start of our romance;

it seemed so promising, and is. Love, continual happiness or not is not what matters.

I cannot tell you, who I want to spend my life with, enough about our love. 